\title{
Urticaria-angioedema paraneoplastic syndrome associated with renal cell carcinoma
}

\section{Sindrome paraneoplásica com urticária e angioedema associado a carcinoma de células renais}

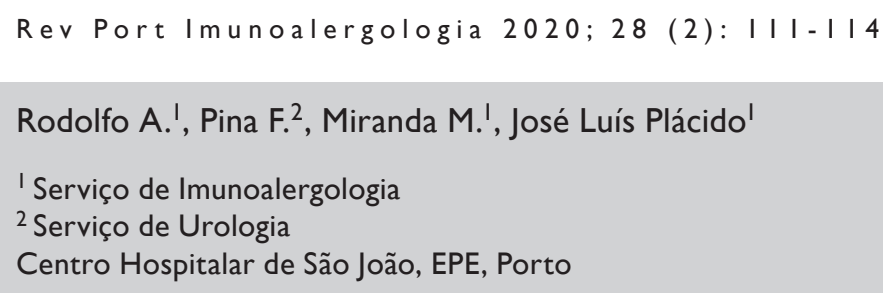

\section{ABSTRACT}

Urticaria and angioedema are part of a benign syndrome in the majority of cases. However, they can occur as paraneoplastic syndromes. A 46 year old woman was observed with urticaria, angioedema and progressive fatigue and adynamia of unknown cause. The urticaria responded to anti-histamines, but the angioedema did not and had a circadian evolution. The urticaria was mild, but the angioedema caused severe episodes. Blood tests revealed normal red and white blood cell counts as, normal renal, liver and thyroid function. Sedimentation rate, complement serum proteins $(\mathrm{Cl}, \mathrm{C} 3, \mathrm{C} 4$ and $\mathrm{Clq}$ ) and $\mathrm{Cl}$-esterase inhibitor concentrations were within normal ranges. A CT-scan demonstrated a $4.8 \mathrm{~cm}$ diameter cyst in the right kidney, deemed as a probable renal cells carcinoma on a posterior Uro-CT-scan. A radical nefro-ureterectomy was successfully performed and tumor histology established a cromophobe renal cells carcinoma (RCC) diagnosis at a PTNM PTIb Nx R0. A few days after surgery, a fast improvement of facial angioedema was observed and one month later its complete disappearance was ascertained, without any recurrence during a subsequent one-year follow-up. The evaluation of patients with urticaria and angioedema does not usually require a lot of complementary tests. However, further study should be considered when these symptoms are present with atypical characteristics.

Keywords: Angioedema, para-neoplastic syndrome, renal cell carcinoma, urticaria. 


\section{RESUMO}

A urticária e o angioedema fazem habitualmente parte de uma síndrome benigna, porém, podem por vezes estar associados a síndromes paraneoplásicos. Uma doente do sexo feminino, com 46 anos, foi enviada a consulta de Imunoalergologia no contexto de urticária, angioedema e fadiga progressiva, de causa desconhecida. A urticária cedia aos anti-histamínicos, porém o angioedema não respondia a estes fármacos e tinha um ritmo circadiano. A urticária era ligeira, enquanto os episódios de angioedema eram mais severos. Foi requisitado estudo analítico, que demonstrou contagem de eritrócitos e leucócitos normais, assim como função renal, hepática e tiroideia sem alterações. Foram também requisitados a velocidade de sedimentação, estudo das proteínas do complemento $(\mathrm{Cl}, \mathrm{C} 3, \mathrm{C4}$ e $\mathrm{Clq})$ e o doseamento de $\mathrm{Cl}$-esterase inibidor, que se encontravam dentro dos limites da normalidade. Uma TC demonstrou um quisto com cerca de 4,8 cm de diâmetro no rim direito, que foi considerado como um provável carcinoma de células renais numa Uro-TC realizada posteriormente. Foi realizada uma nefro-ureterectomia radical. $O$ estudo anatomopatológico revelou um carcinoma de células renais cromófobo, com estadiamento pTNM pTIb Nx RO. Durante o primeiro mês após a cirurgia, verificou-se uma rápida melhoria dos episódios de angioedema. Após o primeiro mês não ocorreram novos episódios de angioedema, com nenhuma recorrência após um ano de seguimento. $A$ avaliação de doentes com urticária e angioedema não requer, habitualmente, a requisição de múltiplos exames complementares de diagnóstico. Porém, deve ser considerado um estudo complementar mais alargado nos doentes em que estes sintomas se manifestam de forma atípica.

Palavras-chave: Angioedema, urticária, síndrome paraneoplásica, carcinoma de células renais.

Urticaria and angioedema may be present as part of a para-neoplastic syndrome. Renal cell carcinoma may manifest as a para-neoplastic syndrome in up to $40 \%$ of cases' ${ }^{\prime}$ but urticaria and angioedema are a very rare manifestation, which has not been described so far.

\section{CLINICAL CASE}

We present the clinical case of a 46-year-old woman reporting de novo spontaneous generalized urticaria and facial angioedema arising approximately four months after initiation of progressive but mild fatigue and adynamia of unknown cause, in the absence of any other warning signs, namely weight loss or anorexia. Interestingly, the urticaria and the angioedema had different characteristics and also evolved differently. Urticaria was usually mild and responded well to anti-histamines in single doses. On the other hand, angioedema, which was predominant on eyelids, lips and tongue, had a circadian rhythm, always beginning in the morning and waning until the afternoon (Figure I). The angioedema did not respond to quadruple doses of anti-histamines nor corticosteroids ( $\mathrm{Img} / \mathrm{Kg}$ of prednisolone), and had the same evolution during the day irrespectively of the administration of these drugs. The episodes of angioedema and urticaria occurred around four times a month, with no need for regular intake of anti-histamines. There was no clear association with any specific food, drug, insect sting, physical activity or other known urticaria inducer. Apart from urticaria and angioedema manifestations, clinical examination showed no major abnormality. The patient had an unremarkable personal and family history. 


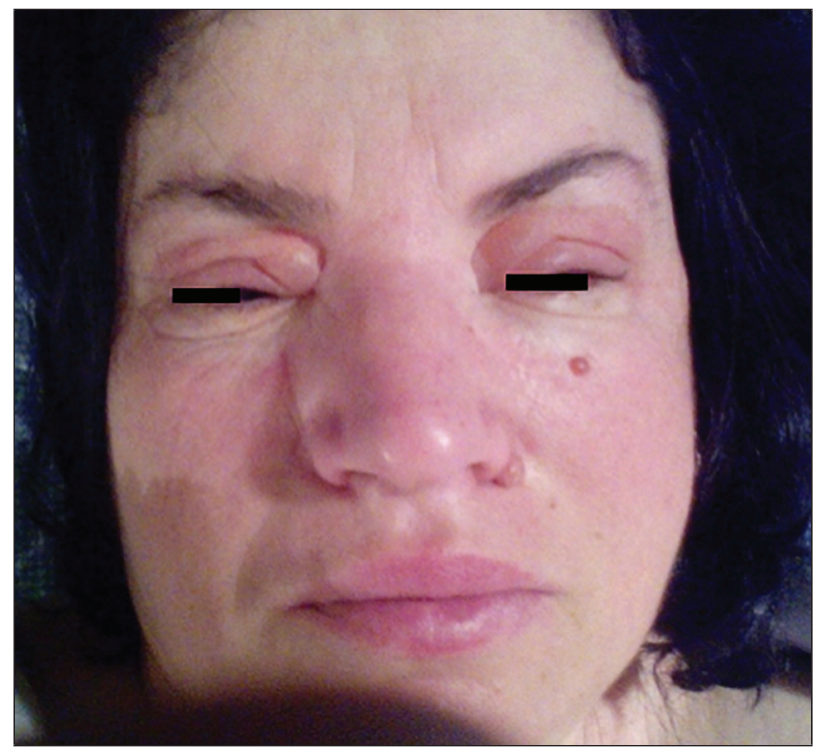

Figura I. One of the episodes of angioedema

Blood tests revealed normal red and white blood cell counts as well as normal renal, liver and thyroid function. Sedimentation rate, complement serum proteins $(\mathrm{Cl}, \mathrm{C} 3$, $\mathrm{C} 4$ and $\mathrm{Clq}$ ) and $\mathrm{Cl}$-esterase inhibitor concentrations were within normal ranges. Thorax-ray was normal. Because of the atypical characteristics of the urticaria and the angioedema, namely the circadian evolution of the angioedema, and the presence of fatigue and adynamia, a thoracic-abdominal-pelvic CT-scan was requested, which revealed a $4.8 \mathrm{~cm}$ diameter cyst at a supero-posterior position in the right kidney (Figure 2). Afterwards, an Uro-CT scan demonstrated characteristics compatible with a probable renal cells carcinoma. A radical nefro-ureterectomy was successfully performed and tumour histology established a cromophobe renal cells carcinoma (RCC) diagnosis, at a PTNM pTIb Nx R0 staging according to the American Joint Committee on Cancer (8. ${ }^{\text {th }}$ edition). A few days after surgery, a fast improvement of facial angioedema was observed and one month later its complete disappearance was ascertained, without any recurrence during a subsequent one-year follow-up. The patient is now under vigilance, as the re-appearance of urticaria and angioedema may be associated with CCR remission.

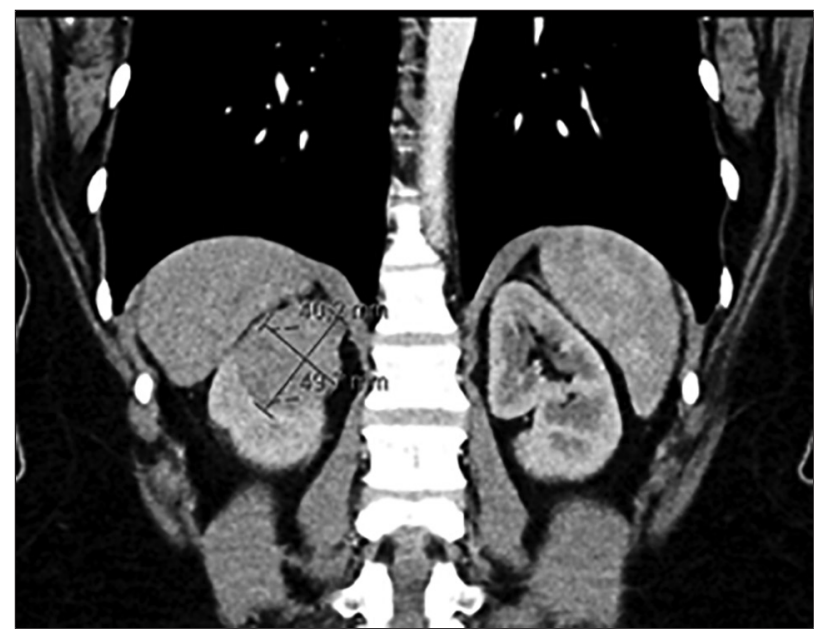

Figura 2. CT-scan: a $4.8 \mathrm{~cm}$ diameter cyst at a supero-posterior position in the right kidney

\section{DISCUSSION}

Chronic spontaneous urticaria may arise in association with systemic or organ-confined neoplastic diseases, configuring a possible paraneoplastic syndrome. To our knowledge this is the first published case of RCC manifesting as urticaria/angioedema.

The five-year survival rate of patients with RCC has doubled over the last 50 years, from $34 \%$ in 1954 to over $62 \%$ in 1996, to $73 \%$ from 2005 to 2011 and to $74.8 \%$ from 2009 to 2015 '. RCC may present with haematuria, abdominal mass, pain and weight loss, nonetheless many patients are asymptomatic until the disease is advanced. When diagnosis is made, approximately $25 \%$ of patients have either distant metastases or advanced locoregional disease ${ }^{2}$. The diagnostic evaluation should begin with CT scan that is usually useful to distinguish a simple benign cyst from a more complex cyst or a solid tumour. The tissue diagnosis is usually made after nephrectomy or partial nephrectomy, although the diagnosis of RCC is occasionally established by a biopsy of a metastasis. Once the presumptive diagnosis has been made, an evaluation of the extent of local involvement and the presence of metastatic disease is in order, 
Rodolfo A., Pina F., Miranda M., José Luis Plácido

as this will allow the RCC staging, which is based on the TNM staging system.

Around $10 \%$ to $40 \%$ of renal cells carcinoma patients will develop a paraneoplastic syndrome but quite rarely urticaria and/or angioedema. Urticaria and angioedema are generally associated with lymphoproliferative diseases and malignancies. Association with solid tumours is less frequent ${ }^{3}$. Several mechanisms have been proposed to explain the origin of urticaria and angioedema as part of paraneoplastic syndromes. One of them refers to ectopic production of proteins by the tumour cells, that act as humoral factors ${ }^{4}$. In these cases, the cancer treatment is accompanied by cessation of the urticaria/angioedema. Translationally Controlled Tumor Protein (TCTP) is an example of a humoral protein produced by different tumour cells like those from colon, prostate, lung and liver cancers ${ }^{5}$. It has already been demonstrated that TCTP induces basophil activation and mast cell degranulation in chronic urticaria, which may explain the presence of urticaria and angioedema as a paraneoplastic syndrome in these types of cancers ${ }^{6}$. It is also plausible that an IgE-mediated auto-immune mechanism against some tumour proteins could exist. In this case, soluble proteins or proteins from tumour cells surface could be recognized by specific IgE which would result in manifestations such as urticaria. On the other hand, some tumour proteins, just like TCTP, could directly activate basophil and mast cells. These hypotheses may be worthy of future investigation.
This clinical case highlights the relevance of a correct diagnostic workup in chronic spontaneous urticaria patients, particularly when atypical characteristics are prominent and accompanied by unspecific systemic disease warning signs.

\section{Conflito de interesses}

Os autores declaram que não existem conflitos de interesse.

Contacto:

Ana Rodolfo

Email: anaiprodolfo@gmail.com

\section{REFERENCES}

I. SEER Stat Fact Sheets: Kidney and Renal Pelvis Cancer. http://seer. cancer.gov/statfacts/html/kidrp.html.

2. Skinner DG, Colvin RB, Vermillion CD, Pfister RC, Leadbetter WF. Diagnosis and management of renal cell carcinoma. A clinical and pathologic study of 309 cases. Cancer 1971;28(5):1165-77.

3. Abreu Velez AM, Howard MS. Diagnosis and treatment of cutaneous paraneoplastic disorders. Dermatol Ther 2010;23(6):662-75.

4. De P, Abbasi R, Senadhira T, Orr P, Ullah A. Urticaria and large cell undifferentiated carcinoma of lung. Dermatol Online J 2005; II(3):45.

5. Chan TH, Chen L, Guan XY. Role of translationally controlled tumor protein in cancer progression. Biochem Res Int 2012:369384.

6. Ulambayar B, Lee H, Yang EM, Park HS, Lee K, Ye YM. Dimerized, Not Monomeric, Translationally Controlled Tumor Protein Induces Basophil Activation and Mast Cell Degranulation in Chronic Urticaria. Immune Netw 2019;19(3):e20. 